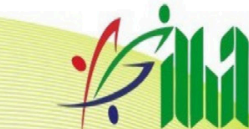 \\ Jurnal Studi Hadis Nusantara
}

Vol. 3 No. 1, Juni 2021

eISSN: 2721-219X

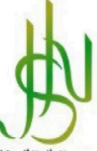

unal Studihadis Husninar

\section{AKTUALISASI NILAI SPIRITUAL DALAM MENGHADAPI PANDEMI COVID-19}

\author{
Theguh Saumantri \\ Institut Agama Islam Negeri Syekh Nurjati Cirebon \\ Saumantri.theguh@syekhnurjati.ac.id \\ Rifqi Ulinnuha \\ Institut Agama Islam Negeri Syekh Nurjati Cirebon \\ linnuha67@gmail.com
}

\begin{abstract}
The Covid-19 Virus pandemic, whose spread was massive and very difficult to handle. Various policies have been implemented by the government to break the chain of virus spreading. The government applies policies in various sectors that can trigger crowds. Because, from the crowd and crowd that is the spread of the virus so quickly and massively. Until the government policy that causes controversy and also the pros and cons among Muslims is the absence of congregational prayers (five-time prayers, Friday prayers, tarawih prayers and Eid al-Fitr prayers) in the mosque for a while. Some agree, because it is for the common good to break the chain of the spread of the virus. And there are also those who disagree with the reason to reduce religious and spiritual values in worship. In this study, a conclusion will be found that spiritual values in human beings in the pandemic can remind ruhaniyah consciousness to connect closely with great power, the values of immortality, finding the meaning of life and beauty.
\end{abstract}

Keyword: Value, Spiritual,Covid 19.

\begin{abstract}
Abstrak
Pandemi Virus Covid-19 yang penyebarannya begitu masif dan sangat sulit untuk ditangani. Berbagai macam kebijakan telah dilakukan pemerintah untuk memutus mata rantai penyebaran virus tersebut. Pemerintah memberlakukan kebijakan di berbagai macam sektor yang dapat memicu keramaian. Sebab, dari adanya keramaian dan kerumunan orang itulah penyebaran virus begitu cepat dan masif. Hingga kebijakan pemerintah yang menimbulkan kontroversi dan juga pro dan kontra di kalangan umat Islam ialah adanya peniadaan shalat berjama'ah (shalat lima waktu, shalat jum'at, shalat tarawih dan shalat hari raya idul fitri) di mushola ataupun masjid untuk sementara waktu. Ada yang setuju, karena demi kebaikan bersama untuk memutus mata rantai penyebaran virus tersebut. Serta ada juga yang tidak setuju dengan alasan mengurangi nilai religius dan spiritual dalam beribadah. Dalam penelitian ini akan didapatkan sebuah kesimpulan bahwa nilai-nilai spiritual
\end{abstract}


dalam diri manusia di masa pandemi dapat mengingatkan kesadaran ruhaniyah untuk berhubungan dekat dengan kekuatan besar nilai-nilai keabadian, menemukan makna hidup dan keindahan

\section{Kata Kunci: Nilai, Spiritual, Covid 19}

\section{Pendahuluan}

Semenjak munculnya virus Covid-19 pada akhir tahun 2019 di Wuhan, China kemudian dengan cepat sudah menyebar ke seluruh dunia pada awal tahun 2020. Penyebaran virus corona bermula di salah satu pasar yang menjual berbagai macam jenis daging hewan, termasuk daging hewan yang buas, bertaring dan memiliki resiko tinggi dalam memaparkan berbagai macam penyakit dan tingkat kebersihan yang sangat sulit terhindarkan. Karena proses pemeliharaan dan penyembelihan yang dilakukan di pasar tersebut. Salah satu hewan yang terindikasi sebagai penyebaran utama virus corona ialah kelelawar. Sebelum dinyatakan adanya penyebaran virus corona yang disebabkan oleh kelelawar, kelelawar sendiri sudah mengandung banyak Virus Zoonosis yaitu HIV, EBOLA, SARS dan juga Rabies ${ }^{1}$

Penyebaran virus corona berhubungan erat dengan sindrom pernapasan akut atau yang disebut SARS yang terjadi dalam kurun waktu satu tahun (2002-2003). Virus SARS begitu cepat ditangani karena bentuk gejalanya yang cukup parah, mudah terdeteksi dan tidak membutuhkan kurun waktu yang lama untuk mengindikasi bahwa seseorang terinfeksi atau tidak. Sedangkan virus corona atau Covid-19 jauh lebih sulit dalam mengidentifikasi bahwa seseorang terpapar virus tersebut atau tidak. Pasalnya virus ini begitu cepat menyebar. Banyak penelitian yang menyebutkan bahwa masa inkubasi virus corona ialah 2-14 hari. Sedangkan gejalanya sendiri baru akan terlihat pada hari

1 "Dari-China-Begini-Cara-PenyebaranVirus-Corona-Ke-Seluruh-Dunia?," accessed May 21, 2020, https://www.suara.com/ health/2020/04/04/183648. ke-5.

Pandemi virus corona membuat berbagai macam kegiatan terhambat. Penyebarannya yang begitu cepat membuat semua orang harus melakukan physical distancing atau social distancing. Mulai dari bekerja, belajar dan juga beribadah di rumah. Masyarakat harus menjaga kebersihan rumah dan tempat kerja dengan menyemprotkan disinfektan serta menjaga kebersihan diri dengan rajin mencuci tangan dan langsung mandi bilamana setelah keluar dari rumah juga senantiasa mengenakan masker dan tidak berjabat tangan terlebih dahulu sampai batas waktu yang ditentukan mengenai pandemi ini. Seluruh rakyat Indonesia juga dihimbau untuk senantiasa menjaga kebersihan badan, dengan terus mandi dan mencuci tangan setelah bepergian dari luar rumah.

Dari adanya pandemi ini, seluruh umat manusia di dunia benar-benar kembali teringat kepada Tuhan. Semua agama termasuk Islam. Semua kegiatan keagamaan yang dilakukan oleh semua agama dialihkan untuk dilakukan di rumah saja. Misalnya seperti Agama Islam, Hindu, Budha, Konghuchu dapat melakukan ibadahnya di rumah secara bersama dengan keluarga masing masing. Sama halnya juga dengan Agama Kristen dan Katholik yang melakukannya di rumah dan juga beberapa di antaranya melakukannya secara virtual. ${ }^{2}$

\section{Motode Penelitian}

Penulisan penelitian ini merupakan penelitian deskriptif kualitatif berbasis field research (penelitian lapangan) dengan

2 MUI, "Fatwa Majelis Ulama Indonesia Nomor: 14 Tahun 2020 Tentang Penyelenggaraan Ibadah Dalam Situasi Terjadi Wabah COVID-19, (2020)," 2020. 
bertujuan untuk mendiskripsikan fakta atau fenomena yang terjadi secara alami serta untuk menggambarkan secara factual dan akurat mengenai fakta atau sifat dan hubungan antara fenomena yang diteliti. ${ }^{3}$ Dalam penelitian deskriptif kualitatif ini akan diupayakan untuk mencari pemahaman tentang kenyataan dari segi perspektif orang yang ahli di bidangnya. Fenomena Covid-19 yang sedang terjadi di Indonesia bahkan di seluruh dunia berdampak kepada aktivitas keberagamaan masyarakat. Dalam tatanan nilai spritualitas, manusia didasari oleh nilai yang terkandung dalam agama yaitu akidah, syari'ah dan akhlak. Keberagamaan di lapangan menjadi ada perubahan dengan diaturnya cara menjalani rutinitas spritualitas di tengah mewabahnya pandemi covid 19 ini. Oleh karena kita dituntut untuk menyikapi situasi ini dengan mengaktualisasikan nilai spiritual. Hasil penelitian ini diharapkan bisa menjadi rujukan dalam menyikapi suatu fenomena atau fakta yang terjadi di kalangan masyarakat.

\section{Hasil Penelitian}

\section{Nilai dan Spiritualitas berdasarkan Ajaran Islam}

Secara umum nilai adalah konsep umum tentang hal-hal yang dianggap baik dalam suatu masyarakat, yang keberadaannya dicita-citakan, diinginkan dan dilaksanakan dalam kehidupan sehari-hari di lingkungan tersebut untuk mencapai tujuan bersama. Baik dari kesatuan sosial terkecil hingga terbesar seperti kelompok sosial, ras, suku, bangsa dan bahkan masyarakat di seluruh dunia. $^{4}$

Nilai-nilai yang terkandung dalam agama Islam cakupannya begitu luas. Ada tiga nilai pokok utama yang terkandung dalam nilai-nilai agama Islam, diantaranya

3 Moloeng, Metodologi Penilitian Kualitatif (Bandung: Remaja Rosda Karya, 2007).

4 "Pengertian Nilai," www.zonareferensi. com, 2020, https://www.zonareferensi.com/ pengertian-nilai. ialah; nilai akidah, nilai syari'at dan nilai akhlak. $^{5}$

Pertama, nilai akidah memiliki peranan yang sangat penting dan fundamental sehingga penempatan nilai akidah berada di posisi paling utama. Secara etimologi berarti credo, creed yaitu sebuah keyakinan hidup dalam arti khas yang memiliki arti pengingkaran yang bertolak dari hati. Maka dari itu akidah adalah urusan yang wajib diyakini oleh hati dan dapat menentramkan jiwa. Aspek nilai akidah tertanam sejak manusia dilahirkan, dan sudah tertuang dalam surah Al-A'raf ayat 172:

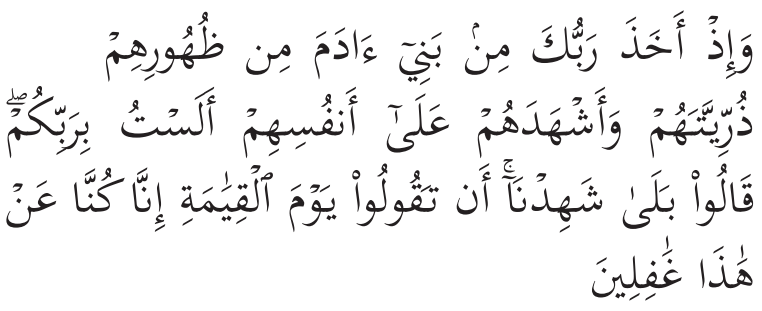

Artinya: "Dan (ingatlah), ketika Tuhanmu mengeluarkan keturunan anakanak Adam dari sulbi mereka dan Allah mengambil kesaksian terhadap jiwa mereka (seraya berfirman): "Bukankah aku ini Tuhanmu?" mereka menjawab: "Betul (Engkau Tuban kami), Kami menjadi saksi”. (kami lakukan yang demikian itu) agar di hari kiamat kamu tidak mengatakan: "Sesungguhnya Kami (Bani Adam) adalah orang-orang yang lengah terhadap ini (keesaan Tuhan)".

Dalam penggalan ayat $\mathrm{di}$ atas menunjukkan, bahwa pada saat sebelum roh dimasukkan ke dalam jasad (bayi 4 bulan dalam rahim ibunya) ruh sudah bersyahadat dengan keyakinan bahwa memang benar tiada Tuhan selain Allah SWT. Namun pada saat sudah lahir di dunia manusia itu sudah lupa siapa Tuhannya. Pada situasi inilah manusia melakukan pencarian terhadap Tuhan. Hingga pada akhir jaman nanti, sudah memiliki keteguhan dan keyakinan

5 Bediuzzaman Said Nursi, Rahasia Kenikmatan Beribadah (Jakarta: Risale Press, 2014). 
bahwa Allah-lah yang paling esa, bukan yang lainnya.

Akidah sebagai sebuah keyakinan akan membentuk tingkah laku, bahkan mempengaruhi kehidupan seorang muslim. Menurut Abu A'la Al-Maududi, pengaruh akidah dalam kehidupan sebagai berikut:

- Menjauhkan manusia dari pandangan yang sempit dan picik.

- Menghilangkan sifat murung dan putus asa dalam menghadapi setiap persoalan dan situasi

- Menanamkan kepercayaan terhadap diri sendiri dan tahu harga diri.

- Menanamkan sifat kesatria, semangat dan berani, tidak gentar menghadapi resiko.

- Membentuk manusia menjadi jujur dan adil.

- Membentuk pendirian yang teguh, sabar, taat dan disiplin dalam menjalankan perintah Ilahi.

- Menciptakan sikap hidup damai dan ridho. ${ }^{6}$

Akidah atau keimanan yang dimiliki setiap orang pasti berbeda-beda. Akidah mempunyai tingkatannya masing-masing yang juga berbeda pula. Tingkatan-tingkatan iman tersebut adalah sebagai berikut:

- Taqlid, tingkatan keyakinan berdasarkan pendapat orang lain tanpa dipikirkan. Dengan kata lain, keyakinan yang dimilikinya adalah meniru ada orang lain tanpa tahu dasarnya.

- Yaqin, tingkatan keyakinan yang didasarkan atas bukti dan dalil yang jelas, tetapi belum menemukan hubungan yang kuat antara obyek keyakinan dengan dalil yang diperolehnya.

- 'Ainul yaqin, tingkatan keyakinan berdasarkan dalil rasional, ilmiah dan mendalam sehingga mampu membuktikan obyek keyakinan dengan dalil-dalil serta mampu

6 Ade Imelda Frimayanti, "Implementasi Pendidikan Nilai Dalam Pendidikan Agama Islam," Al-Tadzkiyyah: Jurnal Pendidikan Islam 8, no. 11 (2017). memberikan argumentasi terhadap sanggahan-sanggahan yang datang.

- Haqqul yaqin, tingkatan keyakinan yang disamping berdasarkan dalildalil rasional, ilmiah dan mendalam, juga mampu membuktikan hubungan antara objek keyakinan dengan dalildalil, serta mampu menemukan dan merasakan keyakinan tersebut melalui pengalaman agamanya. ${ }^{7}$

Kedua, nilai syari'ah berupa AlQur'an, As-Sunnah dan beberapa pemikiran hasil dari mujaddid dan juga hasil ijtihad dari beberapa ulama. Nilai syari'ah juga dapat diartikan sebagai pengatur hubungan antara Allah dengan manusia, manusia dengan manusia dan manusia dengan alam. ${ }^{8}$

Menurut Taufik Abdullah, syari'ah mengandung nilai-nilai baik dari aspek ibadah maupun muamallah. Nilai-nilai tersebut diantaranya adalah:

- Kedisiplinan dalam beraktifitas untuk beribadah. Hal ini dapat dilihat dari perintah shalat dengan waktu-waktu yang telah ditentukan, seperti dzuhur, ashar, maghrib, isya, dan subuh.

- Sosial dan kemanusiaan.

- Keadilan Islam sangat menjujung tingggi nilai-nilai keadilan. Hal ini bisa dilihat dalam waris, jual, hudud (hukuman), maupun pahala dan dosa.

- Persatuan dalam hal ini terlibat pada sholat berjamaah, anjuran dalam pengambilan saat musyawarah.

- Tanggung jawab dengan adanya aturan-aturan kewajiban manusia sebagai hamba kepada TuhanNya adalah melatih manusia untuk bertanggung jawab atas segala hal yang dilakukan. ${ }^{9}$

Nilai-nilai syari'ah yang sudah Allah SWT. tetapkan melalui Al-Qur'an dan para utusannya agar dapat menuntun manusia menuju ke kehidupan yang lebih hakiki.

Ketiga, nilai akhlak. Secara etimologi istilah "akhlak" dalam bahasa

7 Ibid. 67

8 Bediuzzaman Said Nursi, Rahasia Kenikmatan Beribadah.

9 Nurul Jeumpa, "Nilai- Nilai Agama Islam," Jurnal Pedagogik 04, no. 02 (2017). 
Arab merupakan jama' dari kata "khuluq" yang mempunyai makna literal sifat, budi pekerti, dan watak. ${ }^{10}$ Dalam bahasa Inggris kata padanannya adalah ethics yang berarti sebuah tingkah laku baik atau moral. ${ }^{11}$ Bangsa Yunani menyebutnya dalam bahasa mereka dengan "ethos" atau "ethikos" yang berarti adat serta kebiasaan, dan dalam bahasa Latin "mores" juga berarti sebuah adat. ${ }^{12}$ Ibnu Manzur melalui Lisan al- 'Arab mengartikan akhlak dengan gambaran batin manusia yang mempunyai kemungkinan sifat baik atau buruk. $^{13}$

Akhlak secara terminologi dapat dikutip melalui pendapat Ibn Maskawaih dalam karyanya Tahdzib al-akhlaq yang mendefinisikan bahwa akhlak adalah keadaan jiwa seseorang yang mendorongnya untuk melakukan perbuatan tanpa terlebih dahulu melalui pemikiran dan pertimbangan. Kemudian dari Imam Al-Ghazali dalam karyanyaIhya'UlumAl-Dinyangmenyatakan, bahwa akhlak adalah gambaran tingkah laku dalam jiwa yang daripadanya lahir perbuatanperbuatan dengan mudah tanpa memerlukan pemikiran dan pertimbangan. ${ }^{14}$

Dengan demikian, dari beberapa pengertian mengenai akhlak. Bahwa sesungguhnya akhlak melekat pada jiwa, yang mana akhlak timbul karena tidak adanya paksaan dalam diri manusia dan bukanlah sebuah kebohongan atau kepura-puraan. Maka dari itu akan lahirlah akhlak kepada Allah yang berupa iman, ihsan, sabar, taqwa, istiqomah, tawakkal, syukur dan sabar. Kemudian akhlak kepada sesama manusia yang berupa menjaga persatuan ukhuwah, rendah hati, gotong royong, adil, dermawan, amanah, bertanggung jawab dan lapang dada.

\section{Pengertian Spiritual}

Secara etimologi, spiritualitas berasal

10 Syafa'atul Jamal, "Konsep Akhlak Menurut Ibn Miskawaih," Tasfiyah Jurnal Pemikiran Islam 1, no. 1 (2017).

11 Ibid 98

12 Fakhry Majid, "Ethical Theories in Islam," E.J. Brill 2 (1991).

13 Muhammad Quraish Shihab, Lentera Hati (Bandung: Mizan Pustaka, 2007).

14 Nurul Jeumpa, "Nilai- Nilai Agama Islam." dari bahasa Latin yaitu Spiritus yang berarti roh, jiwa, semangat. Dari kata Latin ini terbentuklah kata Prancis yaitu l'spirit dan kata bendanya la spiritualite. Dalam bahasa Inggris yaitu spirituality, yang dalam bahasa Indonesia menjadi kata spiritualitas. Tujuan spiritualitas adalah manusia. Apabila wilayah psikologi mengkaji jiwa sebagai ego, sedangkan spiritual mengkaji jiwa sebagai spirit. Manusia bermaksud untuk membuat diri dan hidupnya dibentuk sesuai dengan semangat dan cita-cita Allah. ${ }^{15}$

Dalam artian yang sesungguhnya, spiritualitas berarti hidup berdasarkan atau menurut roh. Konteks yang berhubungan dengan transenden. Spiritualitas adalah hidup yang didasarkan pada pengaruh dan bimbingan Allah. Spiritualitas juga dapat diartikan sebagai bidang penghayatan batiniyah terhadap Tuhan melalui laku-laku tertentu yang sebenarnya terdapat pada setiap agama, tetapi tidak semua pemeluk agama menekuninya yang biasanya disebut sebagai penghayat dalam budaya kejawen. ${ }^{16}$

Sudah menjadi kodrat manusia, bahwa ia ditakdirkan sebagai homo religiosus, makhluk yang memiliki naluri kesadaran akan nilai religius. Sudah sejak dulu kala manusia mempercayai akan adanya kekuatan yang jauh lebih besar di luar diri mereka atau yang biasa disebut dengan kekuatan supranatural atau transendental yang menciptakan dan mengatur semua yang ada di alam semesta ini. Perkembangan kepercayaan yang begitu signifikan juga menyesuaikan dengan kondisi sosial-religius di lingkungan masyarakat tersebut. Timbulnya kepercayaan akan adanya kekuatan yang lebih besar dari diri manusia ialah melalui; rasa takut, kagum dan takjub dari adanya fenomena yang terjadi di alam semesta seperti gerhana matahari, gerhana bulan, terbit serta terbenamnya matahari, pelangi, hujan, kemarau, gempa, tsunami, guntur, gunung meletus dan lain

15 Ali Maksum, Tasawuf Sebagai Pembebasan Manusia Modern: Telaah Signifikasi Konsep Tradisionalisme Islam (Surabaya: PS4M, 2003). 16 Ngainun Naim, "Kebangkitan Spiritualitas Masyarakat Modern," Kalam: Jurnal Studi Agama Dan Pemikiran Islam 7, no. 2 (2013). 
sebagainya. ${ }^{17}$

Selain itu terdapat juga beberapa faktor-faktor yang berhubungan dengan spiritualitas, yaitu:

- Diri sendiri, setiap jiwa individu merupakan hal yang paling fundamental dalam menggali nilainilai spiritualitas.

- Masyarakat, adanya hubungan antara individu dengan masyarakat luas menjadi salah satu pokok empirik sebagai manusia biasa. Sehingga menjadi penting dalam meningkatkan spiritualitas bersama masyarakat.

- Tuhan, pemahaman akan Tuhan secara tradisional ialah hanya terdapat melalui kerangka agama. Namun, berbeda dengan pemahaman dan pendekatan terhadap Tuhan di zaman sekarang yang melalui keindahan alam dan seni. ${ }^{18}$

Spiritualitas sebagai salah satu bentuk dari kesadaran ruhaniyah manusia untuk berhubungan dekat dengan kekuatan besar, nilai-nilai keabadian, menemukan makna hidup dan keindahan. Membangun keharmonisan dan keselarasan dengan alam, serta dapat menangkap sinyal dan pesan dari dunia gaib yang memiliki beberapa aspek, yaitu:

- Prayer Fulfillment (pengamalan ibadah) yaitu sebuah perasaan gembira dan bahagia yang disebabkan oleh keterlibatan diri dengan yang transenden. Dalam hal ini dapat mengambil manfaat ibadah yang telah dilakukan.

- Universality (universalitas) yaitu sebuah keyakinan akan kesatuan kehidupan alam semesta dengan dirinya.

- Connectedness (keterkaitan) yaitu sebuah keyakinan bahwa seseorang merupakan bagian dari realitas manusia yang lebih besar yang melampaui generasi dan kelompok

17 Ibid. 57.

18 M. Sobirin dan Rosihan Anwar, Kamus Tasawuf (Bandung: Remaja Rosda Karya, 2000). tertentu. ${ }^{19}$

\section{Penerapan Nilai Spiritual di Masa Pandemi Covid-19}

Pandemi virus Covid-19 yang melanda seluruh negara di dunia, membuat berbagai macam kegiatan terhambat dan salah satunya ialah beribadah mulai dari agama Islam, Kristen, Katholik, Hindu, Buddha dan Konghuchu. Terutama agama Islam di Indonesia dalam menjalankan praktek beribadah shalat lima waktu sehari yang biasa dilakukan secara berjama'ah di mushola atau di masjid kini dilaksanakan di rumah masing-masing karena adanya wabah virus Covid-19 bagi daerah yang ditelah diberi label zona merah oleh pemerintah daerah ataupun pusat. Sedangkan di beberapa daerah yang masih dinyatakan sebagai zona hijau oleh pemerintah, tetap melaksanakan shalat berjama'ah di mushola atau di masjid namun sesuai dengan protokol kesehatan yang telah ditentukan oleh pemerintah dengan memberi jarak ketika shalat sepanjang $1-1,5$ meter. ${ }^{20}$

Seperti yang dikatakan oleh Asrorun Niam Sholeh (Sekretaris Komisi Fatwa MUI) "Demi menjaga kesehatan bersama, dihimbau untuk seluruh masyarakat di setiap daerah untuk melaksanakan ibadah di rumah untuk memutus mata rantai penyebaran virus corona. Disamping itu dengan tetap di rumah dapat mengeratkan hubungan keluarga antara satu sama lain." 21

Walau sebesar apapun pahala shalat berjama'ah di mushola ataupun masjid, bila di masa pandemi seperti ini tetap memaksa untuk melakukannya, tidak menghiraukan kesehatan diri sendiri ataupun orang lain itu sama saja suatu hal yang buruk, karena

19 Maksum, Tasawuf Sebagai Pembebasan Manusia Modern: Telaah Signifikasi Konsep Tradisionalisme Islam.

20 Devia Indriyani Karyono Karyono, Rohadin Rohadin, "Penanganan Dan Pencegahan Pandemi Wabah Virus Corona (Covid-19)," Jurnal Kolaborasi Resolusi Konflik 2, no. 2 (2020), https://doi.org/https://doi.org/10.24198/ jkrk.v2i2.29127.

21 "Cegah-Covid-19-Mui-Shalat-Di-RumahAdalah-Keutamaan," nasional.kompas.com, 2020. Diakses kapan? 
dapat membahayakan orang lain. Bahkan bisa mendapatkan dosa dengan menyebarkan virus, karena virus ini penularannya begitu cepat dan gejalanya yang terlihat begitu lama. Sebab tidak mudah mendeteksi orang tersebut terpapar virus atau tidak. Maka dari itu diharapkan kepada umat Islam diperintahkan untuk melaksanakan ibadah di rumah masing-masing.

Menerapkan nilai-nilai spiritual yang dapat mendekatkan diri kepada Allah SWT di masa pandemi seperti sekarang ini tidak perlu pergi ke mushola ataupun masjid. Ada banyak sekali nilai-nilai spiritual yang bisa membuat kita menjadi dekat kepada sang maha pencipta. Beberapa poin pentingnya ialah makna Hablum Minallah, Hablum Minannas, dan Hablum Minal 'Alam.22

Pertama, Hablum Minallah ialah bagaimana manusia bisa berhubungan baik dengan Allah. Di sini banyak sekali ibadah-ibadah yang dapat mendekatkan hubungan antara seorang hamba kepada Tuhannya. Ibadah-ibadah yang dapat dilakukan di masa pandemi ialah sebagai berikut:

- Shalat fardhu, yaitu shalat yang biasa dikerjakan sebanyak lima waktu diantaranya ialah dzuhur, ashar, maghrib, isya dan subuh. Selain itu ada shalat jum'at yang hukumnya fardhu 'ain bagi para laki-laki muslim.

- Shalat sunnah, yaitu ada shalat sunnah rawatib (qabliyah dan ba'diyah), shalat sunnah dhuha, shalat sunnah tasbih, shalat sunnah tahajud, shalat sunnah istikharah, shalat sunnah taubat dan shalat sunnah hajat.

- Puasa sunnah, puasa yang bila dikerjakan mendapatkan pahala dan bila tidak dikerjakan juga tidak akan mendapatkan dosa. Selain itu, puasa sunnah juga dapat menahan hawa nafsu dari segala macam jenis godaan duniawi. Puasa sunnah yang dianjurkan ialah puasa sunnah seninkamis, puasa sunnah Nabi Daud.

- Berdzikir, dengan berdzikir kita senantiasa mengingat Allah SWT. serta, memperbaiki hubungan

22 Nurul Jeumpa, "Nilai- Nilai Agama Islam." seorang hamba dan sang pencipta yang terpisah jauh. ${ }^{23}$

Kedua, Hablum Minannas ialah hubungan manusia dengan manusia yang lainnya. Di masa pandemi seperti ini dan adanya perintah untuk social distancing atau physical distancing, banyak masyarakat yang justru malah salah mengartikannya. Dengan tidak membantu satu sama lain karena rasa khawatir dan takut yang tinggi terhadap virus Covid-19. Banyak sekali kasus dan laporan mengenai orang yang terinfeksi virus ini justru dijauhi dan dikucilkan. Menjaga jarak terhadap seseorang yang terinfeksi virus ini memanglah sebuah keharusan. Sebuah kesalahan besar juga bilamana kita tidak mempedulikan dan mengucilkan orang yang terinfeksi virus tersebut. Menjaga jarak bukan berarti kita harus menjauhinya dan tidak memperdulikan mereka selayaknya manusia pada umumnya. ${ }^{24}$

Justru dari adanya pandemi ini kita bisa membantu satu sama lain. Terutama terhadap seseorang yang terinfeksi virus covid-19 dan melakukan isolasi mandiri di rumahnya. Kita dapat membantunya dengan cara memberikan makanan dan minuman yang bisa ditinggalkan di depan pintu rumahnya, karena situasi mereka yang tidak diperbolehkan untuk keluar kemana-mana. Dengan membantu mereka kita dapat menumbuhkan rasa saling kasih sayang antara satu dengan yang lain, juga mempererat hubungan sosial masyarakat walaupun melalui protokol kesehatan yang sudah ditentukan tanpa harus menghilangkan nilai-nilai kemanusiaan.

Ketiga, Hablum Minal 'Alam adalah hubungan antara manusia dengan alam yang ada disekitarnya. Hubungan yang dijalin manusia tidak hanya sebatas kepada Tuhan dan sesama manusia saja. Namun demikian juga dengan alam. Di saat masa pandemi seperti ini Hablum Minal 'Alam sangat dijunjung tinggi. Penyebaran virus covid-19 yang sangatlah masif dan penularannya

23 Bediuzzaman Said Nursi, Rahasia Kenikmatan Beribadah.

24 Karyono Karyono, Rohadin Rohadin, "Penanganan Dan Pencegahan Pandemi Wabah Virus Corona (Covid-19).” 
tidak hanya melalui udara, batuk, bersin dan berjabat tangan saja. Melainkan juga virus tersebut dapat menempel diberbagai macam benda yang disentuh oleh orang yang terinfeksi virus tersebut. ${ }^{25}$

Kebersihan sangatlah diutamakan di masa pandemi ini. sesuai dengan protokol kesehatan yang diditetapkan oleh pemerintah untuk senantiasa cuci tangan sehabis memegang benda apapun itu, jangan mengucek mata, menyentuh hidung, menjaga kebersihan badan, rumah dan lingkungan sekitar. ${ }^{26}$

Berbagai macam kebijakan yang diberlakukan oleh pemerintah di seluruh dunia untuk memutus mata rantai virus covid-19 ini. salah satunya ialah dengan diberlakukannya lockdown. Kebijakan lockdown dianggap dapat memutus mata rantai penyebaran virus tersebut. Dengan diberlakukannya kebijakan lockdown dibeberapa negara yang penyebaran virusnya sangatlah tinggi tetapi membuat udara di negara tersebut semakin sejuk dan tingkat polusi semakin menurun. Ini menunjukkan bahwa kebijakan tersebut juga sangatlah baik untuk alam. ${ }^{27}$

Selain itu di beberapa tempat wisata baik itu kota, pedesaan ataupun pegunungan menerapkan protokol kesehatan dan kebersihan yang sangat ketat menjelang new normal. Penerapan protokol kesehatan dan kebersihan ditempat wisata disinyalir untuk menjaga kebersihan agar menekan penyebaran virus tersebut dan menjaga lingkungan atau alam sekitar agar tetap bersih.

Seperti yang dikatakan oleh beberapa sufi terkemuka, terutama di bidang Tasawuf yaitu Ibn 'Arabi (1165-1240), bahwa alam adalah bentuk manifestasi atau bayangan dari Tuhan. Begitupun dengan manusia itu

25 Erni Isnaeniah Dadang Darmawan, Deni Miharja, Roro Sri Rejeki Waluyajati, "Sikap Keberagamaan Masyarakat Menghadapi Wabah COVID-19,"Religious 4, no. 2 (2020), https://doi. org/https://doi.org/10.15575/rjsalb.v4i2.8596.

26 Karyono Karyono, Rohadin Rohadin,

"Penanganan Dan Pencegahan Pandemi Wabah Virus Corona (Covid-19)."

27 8Ibid. 167 sendiri. Sebab, mengenal Tuhan itu tidak hanya melalui ibadah syari'at, dengan terus menggali potensi diri dan menjaga lingkungan adalah salah satu cara menuju Tuhan pula. ${ }^{28}$

\section{Penutup}

Masa pandemi Covid-19 dapat dimanfaatkan untuk mengenal dan mendekatkan diri kepada Tuhan, melalui kontemplasi diri dan mengaktualisasikan nilai-nilai spiritual bagi diri sendiri, kepada orang lain dan juga kepada alam. Setiap cobaan yang Tuhan berikan kepada semua makhluk ciptannya ialah bertujuan untuk mengingatkan manusia supaya mau mendekatkan diri pada-Nya. Karena selama ini manusia selalu sibuk dengan dunia atau dalam bahasa agama disebut dengan hubbud dunya. Maka dari itu melalui beberapa tahapan dan beberapa penjelasan mengenai hal apa saja yang dapat diterapkan untuk mendekatkan diri pada Tuhan sudah dijelaskan di atas untuk bisa diterapkan pada masa pandemi dan seterusnya.

Karena nilai-nilai dalam spiritualitas tidak akan pernah lepas dalam kehidupan sehari-hari. Seperti dalam paham pantheisme; bahwa manusia, alam atau lingkungan hidup, bahkan seluruh yang ada di alam semesta merupakan cerminan atau bayangan Tuhan. pada hakikatnya semua yang berasal dari Tuhan akan berakhir juga pada Tuhan.

\section{Daftar Pustaka}

Ade Imelda Frimayanti. "Implementasi Pendidikan Nilai Dalam Pendidikan Agama Islam." Al-Tadzkiyyah: Jurnal Pendidikan Islam 8, no. 11 (2017).

Bediuzzaman Said Nursi. Rahasia Kenikmatan Beribadah. Jakarta: Risale Press, 2014.

nasional.kompas.com. "Cegah-Covid19-Mui-Shalat-Di-Rumah-AdalahKeutamaan," 2020.

Dadang Darmawan, Deni Miharja, Roro Sri Rejeki Waluyajati, Erni Isnaeniah. "Sikap Keberagamaan Masyarakat

28 M. Sobirin dan Rosihan Anwar, Kamus Tasawuf. 
Menghadapi Wabah COVID-19." Religious 4, no. 2 (2020). https://doi. org/https://doi.org/10.15575/rjsalb. v4i2.8596.

"Dari-China-Begini-Cara-PenyebaranVirus-Corona-Ke-Seluruh-Dunia?" Accessed May 21, 2020. https://www. suara.com/health/2020/04/04/183648.

Karyono Karyono, Rohadin Rohadin, Devia Indriyani. "Penanganan Dan Pencegahan Pandemi Wabah Virus Corona (Covid-19)." Jurnal Kolaborasi Resolusi Konflik 2, no. 2 (2020). https:// doi.org/https://doi.org/10.24198/jkrk. v2i2.29127.

M. Sobirin dan Rosihan Anwar. Kamus Tasawuf. Bandung: Remaja Rosda Karya, 2000.

Majid, Fakhry. "Ethical Theories in Islam." E.J. Brill 2 (1991).

Maksum, Ali. Tasawuf Sebagai Pembebasan Manusia Modern: Telaah Signifikasi Konsep Tradisionalisme Islam. Surabaya: PS4M, 2003.

Moloeng. Metodologi Penilitian Kualitatif. Bandung: Remaja Rosda Karya, 2007.

MUI. "Fatwa Majelis Ulama Indonesia Nomor: 14 Tahun 2020 Tentang Penyelenggaraan Ibadah Dalam Situasi Terjadi Wabah COVID-19, (2020)," 2020.

Ngainun Naim. "Kebangkitan Spiritualitas Masyarakat Modern." Kalam: Jurnal Studi Agama Dan Pemikiran Islam 7, no. 2 (2013).

Nurul Jeumpa. "Nilai- Nilai Agama Islam." Jurnal Pedagogik 04, no. 02 (2017).

www.zonareferensi.com. "Pengertian Nilai," 2020. https://www.zonareferensi.com/ pengertian-nilai.

Shihab, Muhammad Quraish. Lentera Hati. Bandung: Mizan Pustaka, 2007.

Syafa'atul Jamal. "Konsep Akhlak Menurut Ibn Miskawaih." Tasfiyah Jurnal Pemikiran Islam 1, no. 1 (2017). 